\title{
References
}

Grūbe, G. (2006). Lubāna ezera attīstības modelēšana: maǵistra darbs. Rīga: LU G̣eogrāfijas un Zemes zinātņu fakultāte, Latvijas Universitāte.

Loze, I. (1990). Arheologiskie izrakumi Ičas neolīta apmetnē. Zinātniskās atskaites sesijas materiāli par arheologu un etnogrāfu 1988. un 1989. gada pētījumu rezultātiem. Rīga: Zvaigzne. 106109.

Paparde, L., Kalniņa, L., Ceriņa, A., Loze, I., Kiziks, K. and Purmalis, O. (2017). Ičas un Lagažas akmens laikmeta apmetņu teritoriju nogulumu raksturojums. Latvijas Universitātes 75. zinātniskā konference. Ģeogrāfija, Geologijia, Vides zinātne. Referātu tēzes. Rīga: LU Akadēmiskais apgāds, 64-67.

PSRS MP Ģeodēzijas un kartogrāfijas galvenās pārvaldes topogrāfiskās kartes M 1:10 000; Topogrāfisko karšu mozaīka M 1:10 000 (1963. g. koord. sistēma, 1976. g. izdevums pēc 1971. g. rekognoscijas datiem). LU ĢZZF WMS. https://www.geo.lu.lv/kartes/ (03.02.2019)

Segliņš, V., Kalniņa, L. and Lācis, A. (1999). The Lubans Plain, Latvia, as a Reference Area for Long Term Studies of Human Impact on the Environment. PACT, 57, 105-129.

Лозе, И.А. (1988). Поселения каменного века Лубанской низины. Мезолит, ранний и средний неолит. Рига: Зинатне. 5-17.

Эберхардс, Г.Я. (1985). Морфогенез долины области последнего материкового оледенения и современные речные процессы. Автореферат дисертации на соискания ученой степени доктора географических наук. Москва: МГУ им. М.В. Ломоносова, 52.

\section{CHANGES OF PEAT PROPERTIES IN DIFFERENTLY AFFECTED PARTS OF THE LAUGA BOG}

\section{Kūdras īpašību pārmaiṇas dažādi ietekmētās \\ Laugas purva dạ̄ās}

\author{
Jānis Dreimanis, Laimdota Kalniṇa, Līga Paparde, Elīna Deksne \\ University of Latvia, Faculty of Geography and Earth Sciences \\ janis.dreimanis85@inbox.lv
}

\begin{abstract}
At the present time much attention on the identification and investigation of degraded peatland areas is mainly being undertaken by studies on growing bog plant species, vegetation cover continuity and character. However, it is also understood that to choose the most effective re-cultivation method it is necessary to know the properties of the remaining peat layers and local hydrological conditions. The aim of this study was to discover the characteristics of peat properties and their changes in three differently affected areas of the Lauga Bog. Field work included geological coring and the collecting of deposit samples for further laboratory analysis including loss on ignition (LOI) analysis, determination of the peat density, $\mathrm{pH}$ and magnetic susceptibility measurements. The obtained results reveal that peat properties in the Lauga Bog vary in differently affected areas. In the affected areas (Lauga-1 and Lauga-3) the top layer of the peat section has a higher natural density and larger proportion of mineral matter. Whereas a natural bog section is characterised by peat with lower natural density, a higher percentage of organic matter and lower $\mathrm{pH}$ is typical for raised bogs.
\end{abstract}

Keywords: natural density, LOI analysis, $p H$, drainage 


\section{Introduction}

At the beginning of the 21 st century special attention was paid to the identification and exploration of affected or degraded peatland areas with cut-over and/or abandoned peat fields. At present, the degree of degradation of the peatlands is mainly assessed by the presence of the moisture-loving bog plant species and the character of vegetation cover. However, it has been found that in choosing the most appropriate re-cultivation method it is necessary to know the properties of the remaining peat layers and other characteristics of the areas for re-cultivation. It is considered that impact on the peatland area also affects the properties of the peat, especially after peat extraction. During the preparation of peatland for peat extraction, the hydrological regime of the field for peat extraction is altered due to drainage and removed vegetation. These measures promote peat compaction and increase of natural density, which also causes an increase in the mineral matter part in peat composition, especially near ditches (Aleksans 2015; Kalniņa et al. 2017).

Peat formation and accumulation in the bogs is mainly influenced by factors such as volume of precipitation, temperature, available oxygen required for aerobic processes, micro-organism colonies, chemical composition of decaying material, composition of peat-forming plants and other properties (Nomals 1930). In the process of peat accumulation, the peat forming plants not only decay and accumulate, but also undergo physical and chemical transformations (Silamiķele 2010). The main characteristics of peat are characterized by a number of indicators, such as degree of decomposition, botanical composition, ash content, moisture, as well as natural density, content and amount of organic matter, minerals and carbonates, $\mathrm{pH}$, conductivity, magnetic sensitivity, etc.

It is considered that re-naturalization of the cut-over peat fields as restoration of the bog vegetation is not always useful. Other scenarios of re-cultivation, such as the planting of berries, forests, sphagnum mosses or other paludicultures, are also considered for rational use and management of these extracted peat fields depending on site conditions and economical aspects. For the realisation of re-cultivation measures, it is important to understand the parameters of the peat properties, the thickness of the remaining peat layers and the character of the hydrological regime. For the best way to assess the changes in the peat properties, research should be undertaken in several differently affected areas, as data comparison and analysis is required.

This study was based on the Lauga Bog investigations, which in the short term was located at differently affected areas. The Lauga Bog as a research location was chosen as it is one of the LIFE REstore project pilot areas, which aim to restore the hydrological regime, and to provide a sustainable and responsible management for the re-use of degraded peatlands in Latvia. Detailed multi-disciplinary studies of three peat sections nearby in the same peatland area have been carried out for the first time, which justifies the novelty of this study and also determines the need for investigation 
with an aim to obtain detailed results so as to better understand the charater of peat properties during their formation and the effects of drainage (Dreimanis et al. 2017).

The Lauga Bog is located on the border between the Piejūra Lowland and the Idumea Highlands, in the southern part of the Metsepole Plain, west from the River Pēterupe (Figure 1). Lauga Bog is a raised type bog or moss bog, which is one of the largest peatlands in the VidusLatvia ((Middle Latvia) Lowland. The Lauga Bog has, as for raised bogs, characteristic vegetation, micro-relief and bog pools including Lake Višieris and Lake Lode (Zelčs 1994; Markots et al. 1989; Markots et al. 1993).

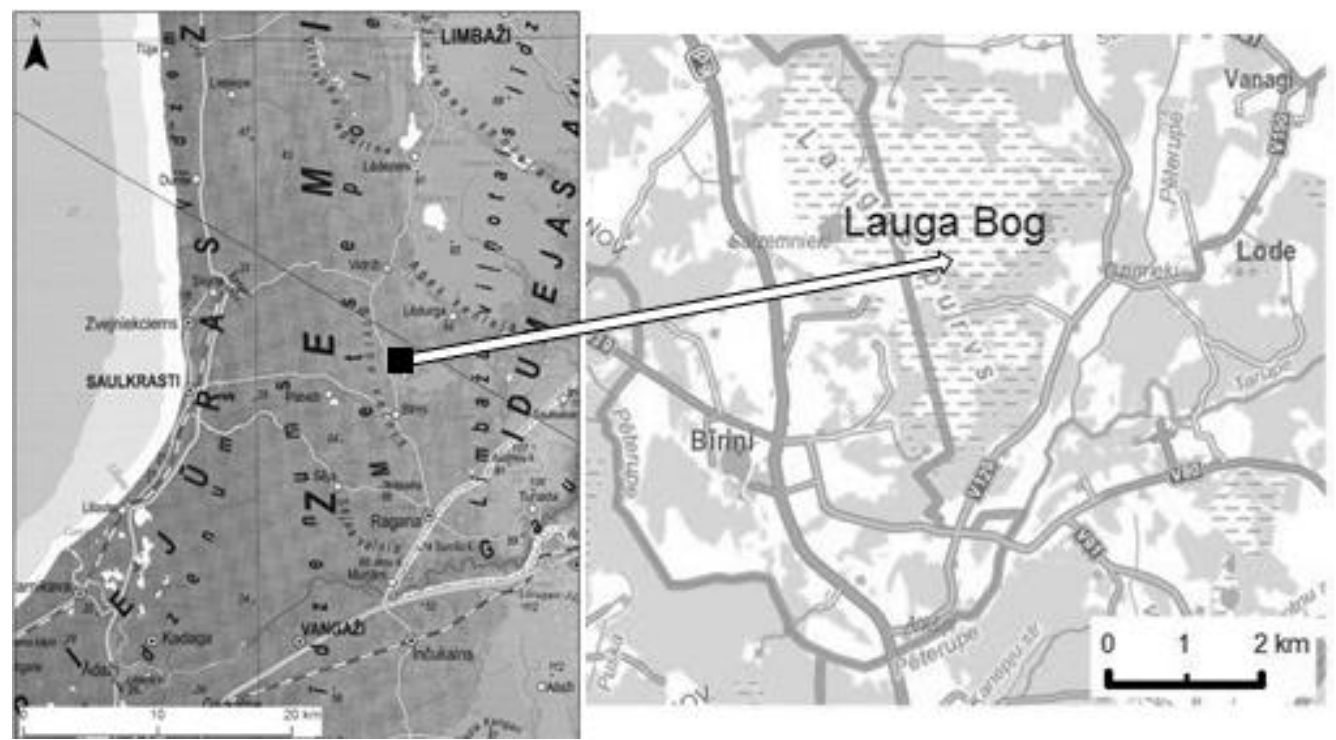

Figure 1. Location of the Lauga Bog (authors' figure using ORTOFOTO 5)

The aim of this study is to find out more about the changes of peat properties from peat sections in three differently affected Lauga Bog areas.

\section{Data and Methods}

Field work. The aim of the field work was to survey the affected and natural areas of Lauga Bog, to choose the most suitable places for study, to carry out geological coring, and to take samples with a camera-type soft sediment corer with a $1.0 \mathrm{~m}$ long camera. The obtained sediment monoliths were then evaluated and documented, assessed for sample colour and structure, and the characterstics noted for the boundaries between different peat types and the degree of peat decomposition according to the L. von Post scale. Taking into account that peat oxidises quickly and changes colour, it was especially important to describe monoliths and to take photos. Afterwards the monoliths were then wrapped in a film to avoid drying and prepared for transportation (Dreimanis et al. 2017).

The study was carried out in the western part of the Lauga Bog, where three different affected areas of the bog are located close to each other (Figure 2). Core Lauga-1 was undertaken in an area where the vegetation cover was removed, and a drainage system with ditches had been installed. Core Lauga- 2 was established in a natural raised bog area at the foot of the bog dome, but core Lauga-3 was prepared in 
an area partially affected by the contour ditch, where vegetation had not been removed, but the contour ditch is at about a $5 \mathrm{~m}$ distance. The Lauga Bog area was chosen for research because it is located close to each of the other different peatland areas. There is an untouched raised bog area, a peat field ready for peat extraction, and a peatland area with vegetation, but which is close to the main ditch.

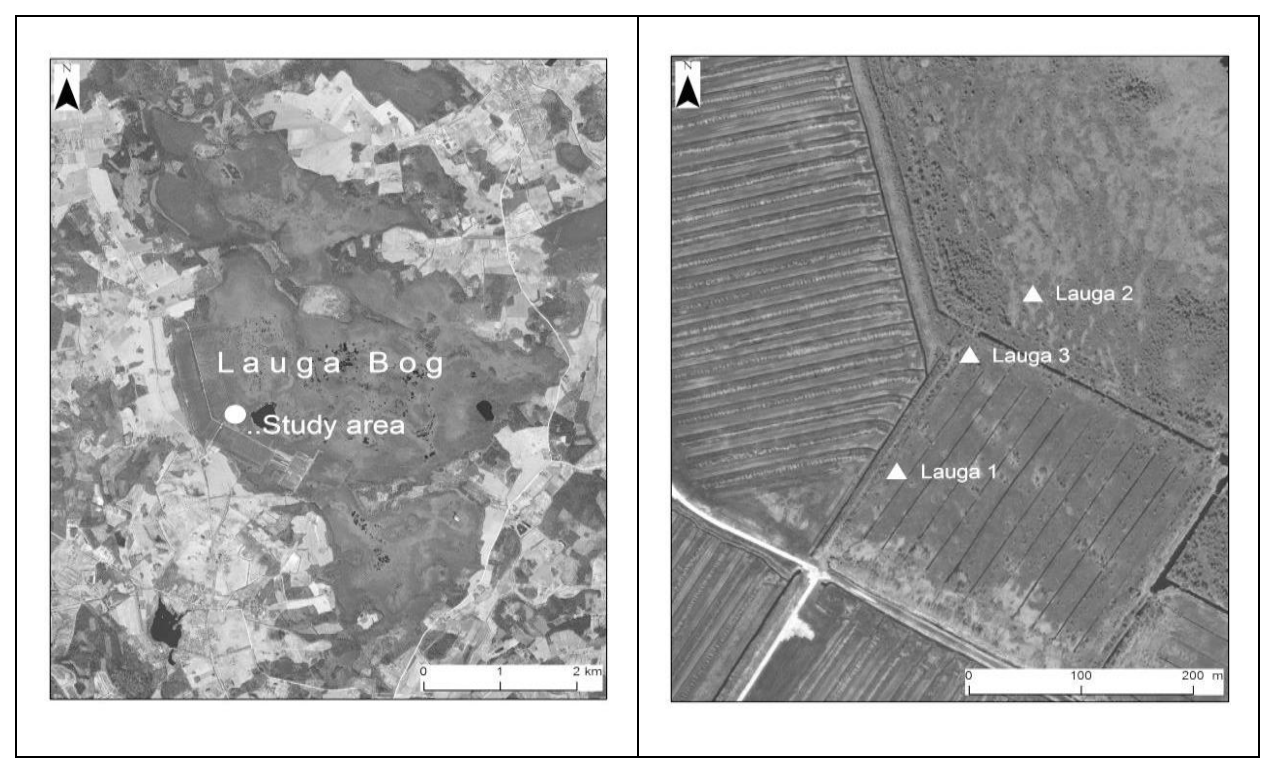

Figure 2. The Lauga bog area and location of coring sites Lauga-1, Lauga-2 and Lauga-

3 layout in differently affected and used areas (authors' figure using ORTOFOTO 5)

Laboratory works and sample processing. In this study the peat deposits from the borehole Lauga-2 were analyzed in detail, as well as the upper layer of the peat section in the depth interval of 0.0-2.0 $\mathrm{m}$ from the boreholes: Lauga-1 and Lauga-3. The following peat research methods were used: natural density determination, loss on ignition (LOI), $\mathrm{pH}$ determination, magnetic sensitivity detection. In general, 2168 samples were used to characterise the peat deposits using these peat research methods (Dreimanis et al. 2017).

\section{Results}

Field work results. During the field work, peat monoliths were obtained (Figure 3). In the core Lauga-1: $4.7 \mathrm{~m}$ is peat, $1.3 \mathrm{~m}$ - clayey blue-algae sapropel with silt admixture, depth of borehole $-6.0 \mathrm{~m}$. In the core Lauga-2: $6.9 \mathrm{~m}$ is peat, $0.1 \mathrm{~m}-$ clayey blue-algae sapropel with silt admixture, depth of borehole $-7.0 \mathrm{~m}$. In the core Lauga-3: $6.7 \mathrm{~m}$ is peat, $0.3 \mathrm{~m}$ - clayey blue-algae sapropel with silt admixture, depth of borehole - $7.0 \mathrm{~m}$ (Dreimanis et al. 2017). 

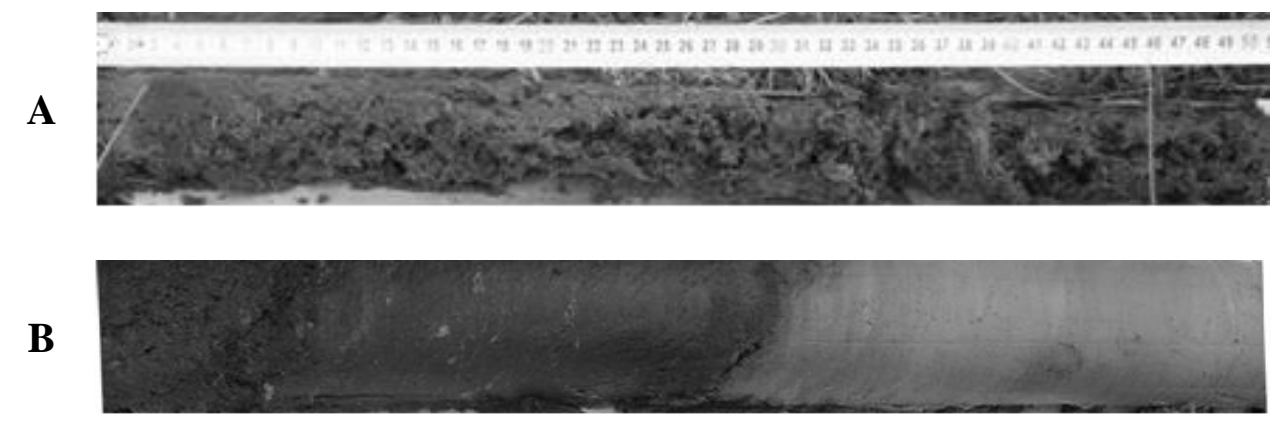

Figure 3. Different deposit types in the Lauga-2 section: A - low decomposed raised bog type Sphagnum peat; B - well decomposed fen type sedge peat in the left part and right part clayey blue-algae sapropel with silt admixture (authors' figure)

Results of laboratory analysis. The natural density analysis of deposits taken from the core of Lauga-1 and Lauga- 3 from the affected part of the peatland have the highest values of natural density (Figure 4), which reveals the influence of drainage on the peat. It is particularly noticeable in the upper interval $(0.00-0.15 \mathrm{~m})$ of the Lauga-3 peat section (Figure 4). The Bog hydrological regime became one of change due to the installing of drainage ditches. This promotes peat drying out and compacting, which affects permanent changes of peat properties, especially with regard to peat natural density (Romanov 1968).

The results of the loss on ignition analysis show that there are small changes in the deposit composition in the largest part of the studied sections. Significant changes started just at the bottom of section, at the depth level where the peat deposit has sapropel admixture and has thus been gradually changed by blue-algae sapropel. In the borehole Lauga-2 (Figure 5) at the depth interval of 0.0-6.15 m, no significant changes were observed in the content of organic matter, mineral matter and/or carbonates. But in the section bottom, at the depth interval $6.15-7.00 \mathrm{~m}$, the amount of organic matter was sharply decreasing and the mineral matter increased significantly. At the lowest depth interval 6.8-7.0 $\mathrm{m}$ an increase was observed in the amount of mineral matter due to silt admixture from the bog depression mineral surface. 


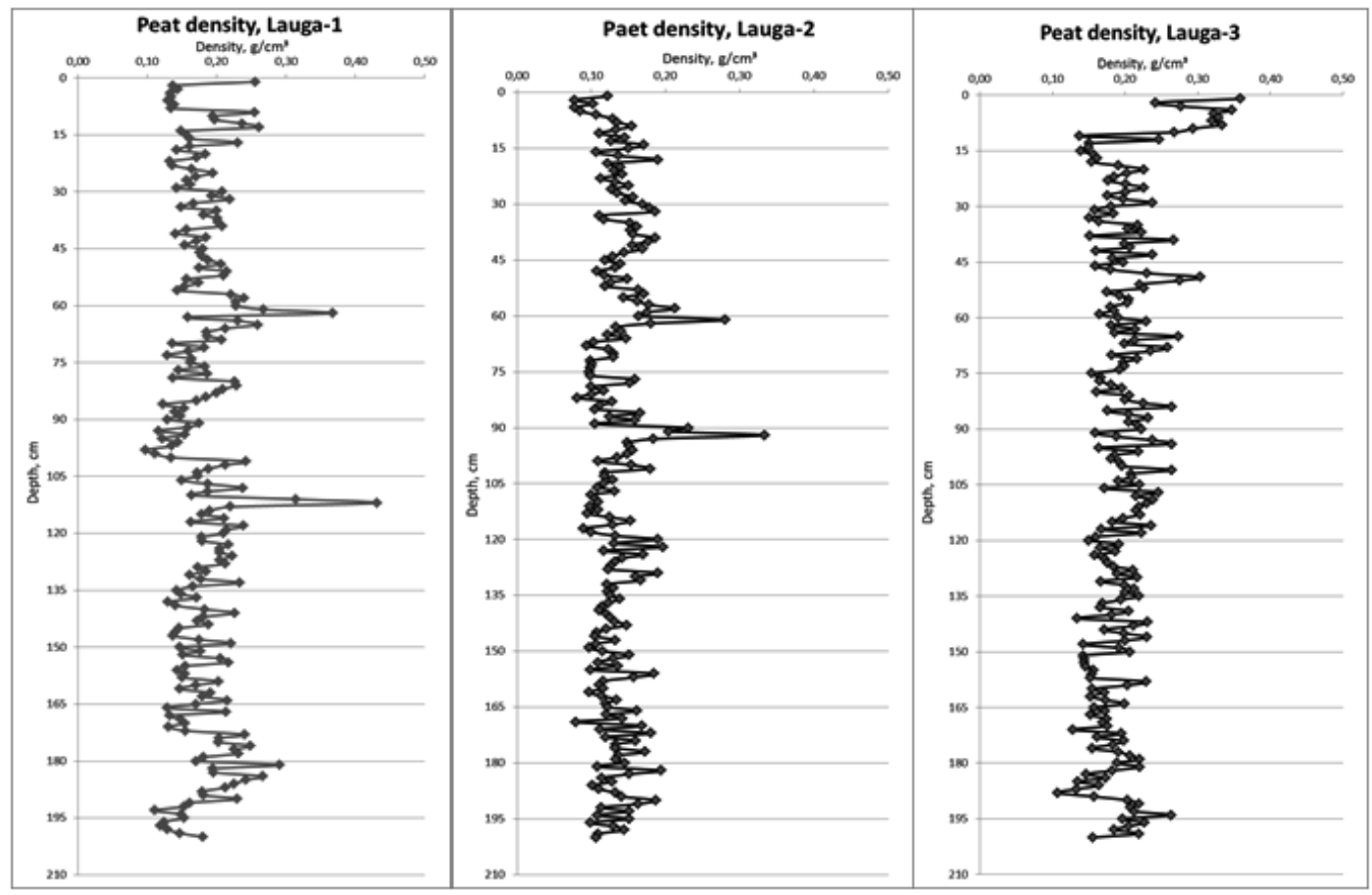

Figure 4. Diagram showing changes in natural peat density in cores Lauga-1, Lauga-2 and Lauga-3 (authors' figure)

Such deposit composition reveals the accumulation of sapropel under the peat and indicates that the Lauga Bog had been formed due to an overgrowing of the shallow water basin. Small changes in the proportions of organic matter and mineral matter were detected in the section Lauga-2 at the depth interval $0.0-6.2 \mathrm{~m}$ and represented by low and medium decomposed raised bog peat. Therefore, results prove that the formation of peat layers took place under stable conditions. Research results do not show significant changes either in deposit composition or peat botanical composition (Dreimanis et al. 2017). However, some sharp and short changes were noticed in the sections Lauga-1 and Lauga-3 from affected areas, which allows us to consider, that it is a drainage influence. Carbonates are very small and their changes are negligible.

Analysis of the $\mathrm{pH}$ in the studied peat sections revealed changes from 3 to 4.7 . The greatest impact of groundwater flows is observed in the borehole Lauga-1 (Figure 6), which is indicated by $\mathrm{pH}=4.7$. The $\mathrm{pH}$ of other boreholes is mainly influenced by precipitation waters, as evidenced by the acid environment $(\mathrm{pH}<4)$, especially for the natural bog Lauga- 2 section. However, there also we find $\mathrm{pH}$ values increase in the upper part of the section in comparison with lower, where $\mathrm{pH}=3$. This might possibly be explained by changes in water level caused by human activities in Lake Višieris located nearby. As it is understood, the inflow of water into the bogs partly explains the $\mathrm{pH}$ level of the peat. Oligotrophic or raised type bogs that plants feed from precipitation waters, have low $\mathrm{pH}$ values, typically <4 (Laine and Vasander 1996; Charman 2002). So, any change in $\mathrm{pH}$ can be associated with anthropogenic affects, even if it is a natural bog, as in this case ... the natural part of the Lauga Bog. 


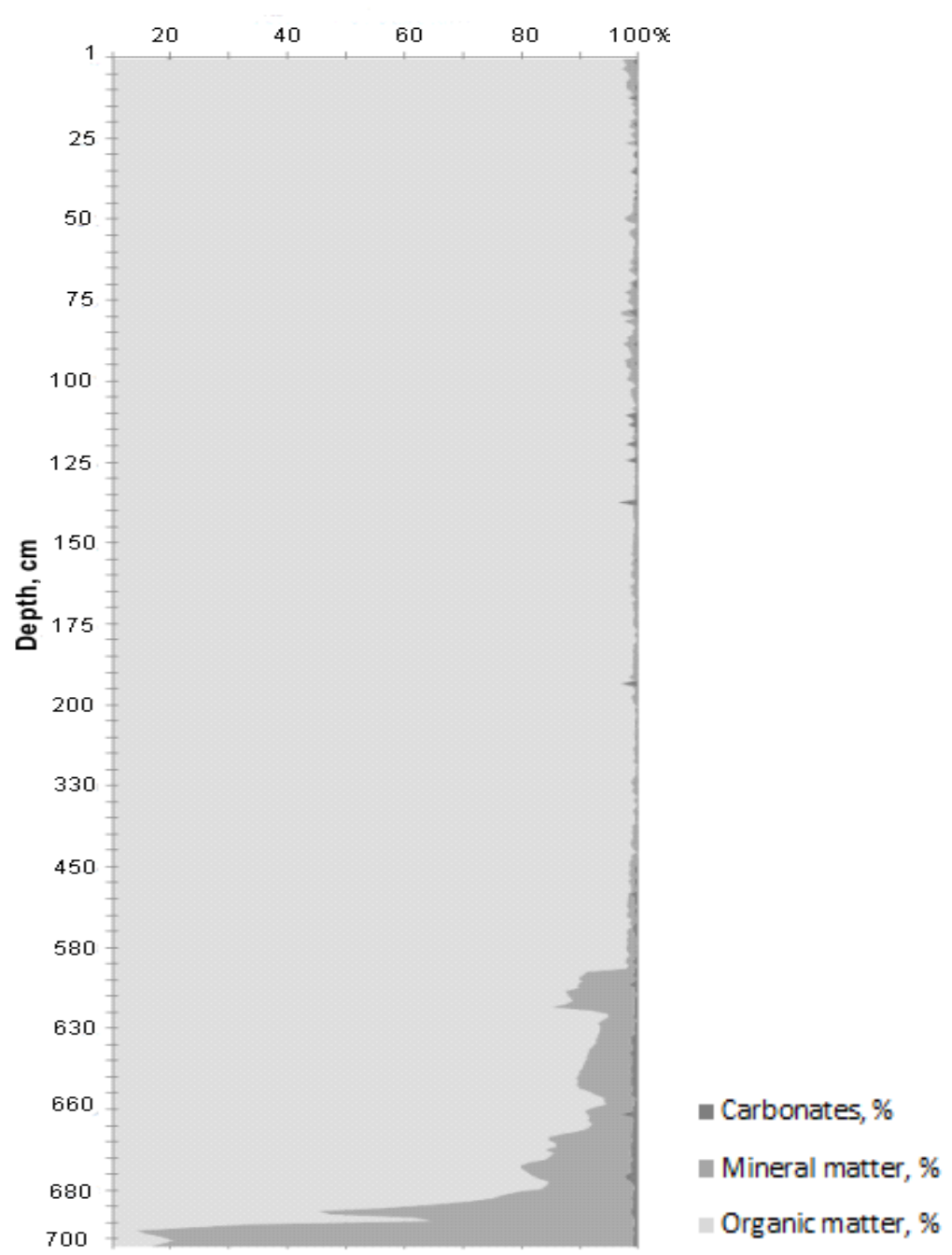

Figure 5. Diagram of Loss on ignition analysis data for deposits in section Lauga-2 (authors' figure)

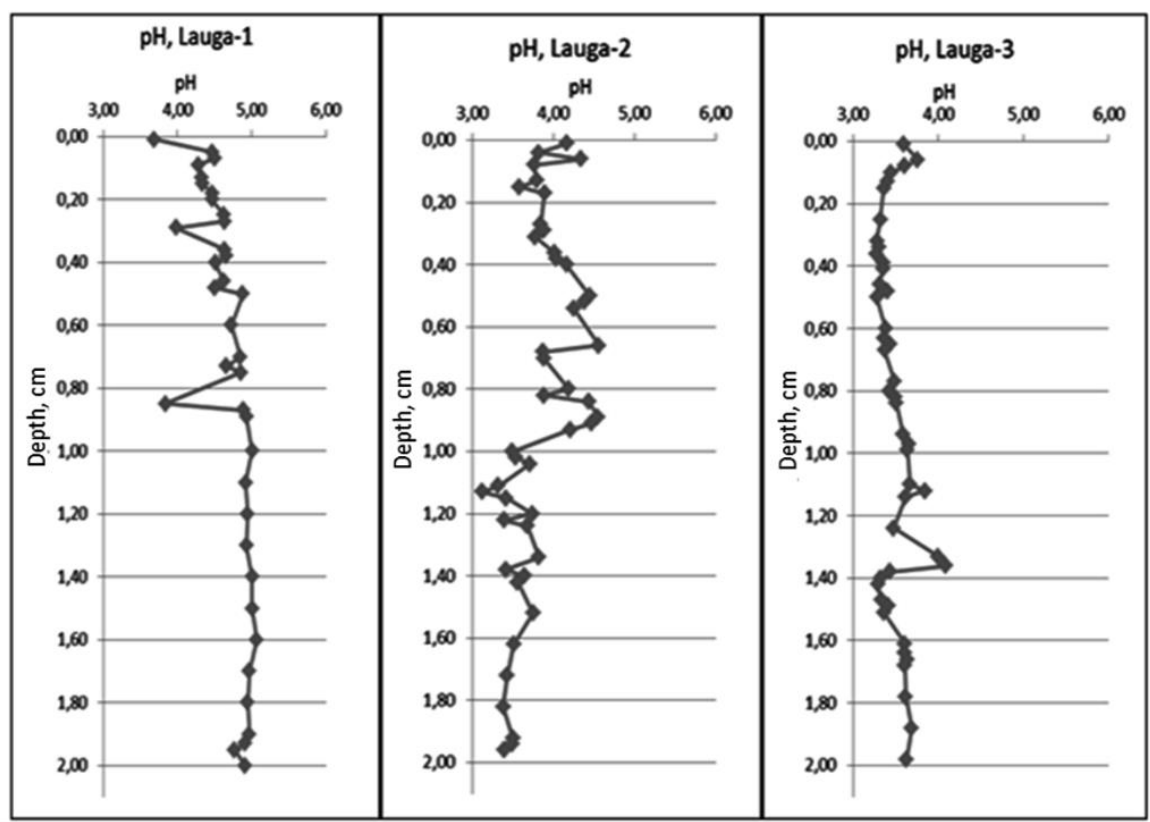

Figure 6. Diagram of $\mathbf{p H}$ results of peat in cores Lauga-1, Lauga-2 and Lauga-3 (authors' figure) 
Negative values for low and high frequency magnetic susceptibility of all boreholes, mean values and their minimum differences indicate that no magnetically susceptible minerals have been detected in the boreholes (Dreimanis et al. 2017).

\section{Conclusion}

The upper peat layer in the affected part of the bog (Lauga-1, Lauga-3) became compacted due to drainage and natural density of peat increase and it is higher than in the natural part of the Lauga Bog (core Lauga-2).

In the affected part of the bog, the core Lauga-1 has two intervals with a rapid decrease in the amount of organic matter, while the section of the natural part (core Lauga-2) has no significant changes in the peat composition which indicates deposit formation under stable conditions.

More pronounced $\mathrm{pH}$ changes occur in the natural part of the bog, where $\mathrm{pH}$ values are low in the lower part but tend to increase upwards from the depth interval, probably also caused by anthropogenic impact. The highest $\mathrm{pH}$ values were detected in the borehole Lauga-1.

In various affected parts of the bog in the range of $0.0-2.0 \mathrm{~m}$, there are negative magnetic susceptibility values indicating that there are no magnetically susceptible minerals in the peat.

Changes of properties in peat sections from degraded areas are different and reveal anthropogenic influence.

\section{Kopsavilkums}

Pètījuma mērkis ir noskaidrot, raksturot un salīdzināt kūdras nogulumu īpašības un to pārmaiņas trīs urbumos, kas atrodas dažādi ietekmētās Laugas purva dą̧ās. Lai noskaidrotu kūdras īpašības un to pārmaiņas, tika veikti lauka pētījumi, tajā skaitā geologiiskā urbšana un nogulumu paraugu iegūšana, lai veiktu analīzes laboratorijā. Šīs analīzes ietvēra kūdras blīvuma noteikšanu, karsēšanas zudumu analīzi, pH, magnētiskā jutīguma analīzi. Iegūtie rezultāti liecina, ka kūdras īpašības Laugas purva dažādi ietekmētajās teritorijās ir atšķirīgas. Purva ietekmētajās dậ̣ās augšējā kūdras slānī ir raksturīgs lielāks kūdras dabīgais blīvums un minerālvielu daudzums. Savukārt purva neskartajā dạ̣ā ir lielāks organisko vielu daudzums, mazāks dabiskais blīvums, kā arī zemāks pH.

\section{References}

Aleksāns, O. (2015). Hidrologiskie un geologiskie pētījumi Ziemeḷu purvu dabas liegumāa. Pārskats. LIFE13 NAT/LV/000578. Prioritāro mitrāju biotopu aizsardzība un apsaimniekošana Latvijā.

Charman, D. (2002). Peatlands and Environmental Change. England: John Wiley \& Sons Ltd.

Dreimanis, J., Kalniņa, L., Krīgere, I. and Paparde, L. (2017). Kūdras īpašǐbu pētījumi dažādi ietekmētajās Laugas purva teritorijās. In: Kḷaviņš, M. (ed.) Rakstu krājums „Kūdra un sapropelis ražošanas, zinātnes un vides sinerǵija resursu efektīvas izmantošanas kontekstā’. Latvijas Universitāte, 2630.

Kalniņa, L., Dreimanis, J., Ozola, I., Bitenieks, R., Dreimanis, I., Krīgere, I. and Nusbaums, J. (2017). Kūdras īpašību izmainas dabas apstākḷu un cilvēka darbības ietekmes rezultātā. In: Kḷaviṇš, M. (ed.) Rakstu krājums „,Kūdra un sapropelis - ražošanas, zinātnes un vides sinerǵija resursu efektīvas izmantošanas kontekstā". Latvijas Universitāte. 51-54.

Laine, J. and Vasander, H. (1996). Ecology and vegetation gradients of peatlands. In: Vasander, H. (ed). Peatlands in Finland. Helsinki: Finnish Peatland Society, 10-19. 
ORTOFOTO 5. ĢZZF WMS - LG̣IA Latvijas 5. etapa ortofoto karšu mozaīka. http://kartes.geo.lu.lv (23.01.2017).

Markots, A., Zelča L. and Zelčs, V. (1989). Augsto purvu fenomens. Zinātne un Tehnika, 11.

Markots, A., Zelča, L. and Zelčs, V. (1993). Dinamiskie sūnekḷi. Latvijas daba: enciklopēdija. 2. sēj. Rīga: Gandrs, 20-21.

Nomals, P. (1930). Latvijas purvi. In: Putniņš, R. (ed.) G̦eogrāfiski raksti. Rīga: Latvijas Ģeogrāfijas biedrība, 1-40.

Romanov, V.V. (1968). Hydrophysics of bogs. Kaner, N. (ed.) Jerusalem: Program for scientific translations Ltd, Jerusalem. 1-299.

Silamiķele, I. (2010). Humifikācijas un ķīmisko elementu akumulācijas raksturs augsto purvu kūdrā atkarībā no tās sastāva un veidošanās. Promocijas darbs. Rīga: Latvijas Universitāte.

Zelčs, V. (1994). Augstā purva mikroreljefs. Enciklopēdija "Latvijas Daba”, 1.sēj. Rīga.

\title{
HUMIC SUBSTANCES AND THE POTENTIAL OF THEIR USE IN AGRICULTURE
}

\section{Humusvielas un to izmantošanas iespējas lauksaimniecībā}

\author{
Māris Kḷaviṇš, Jānis Šìre, Laura Kḷaviṇa \\ University of Latvia, Department of Environmental Science \\ maris.klavins@lu.Iv
}

\begin{abstract}
Most important properties of the major soil and peat organic component - humic substances have been compared, depending on their origin, including the isolation, basic properties, and recent concepts about the structure of humic substances. The influence of humic substances on plant growth has been re-assessed in light of the growing use of humic products in agriculture, and the most prospective areas for humus application have been evaluated. The properties of humic substances possibly influencing their impact on plant growth and, in general, their role in the environment have been analysed. Peat humic substances have substantial potential for use in agriculture.
\end{abstract}

Keywords: natural organic matter; agriculture; biological activity

\section{Introduction}

Humic substances (HS) are the main component of soil and peat organic matter (SOM), comprising up to $60-70 \%$ of content, but at the same time humic substances can be considered as one of the key elements in the bio-geo-chemical turnover of carbon, possibly being the most abundant of naturally occurring organic macromolecules on Earth $\left(2-3 \times 10^{10} \mathrm{t}\right.$ ) (Jones and Bryan 1998). As far as HS are able to interact with inorganic and organic substances, they act as carriers for the many influencing fluxes of elements in the environment. They also play an important role in the formation of fossil fuels and mineral deposits (MacCarthy 2001).

Humic substances are a general category of naturally occurring, biogenic, heterogeneous organic substances that can generally be characterized as being yellow to black in colour, of high molecular weight, and refractory (Aiken et al. 1985).

They consist of several groups of substances that, depending on their solubility, can be grouped as: humin which is the fraction of humic substances that is not soluble 